\title{
Investigation of High-frequency Vacuum Drying on Physical and Mechanical Properties of Common Oak (Quercus robur) and Common Walnut (Juglans regia) Lumber
}

\author{
Cengiz Guler, ${ }^{\mathrm{a}, *}$ and Burak Dilek ${ }^{\mathrm{b}}$ \\ In conventional drying kilns, the drying of especially thick lumber is not \\ ideal in terms of drying quality and drying time. Therefore, it is important \\ to dry thick and dense lumber by high-frequency electromagnetically \\ heated vacuum drying. In this study, common oak (Quercus robur) and \\ common walnut (Juglans regia) selected from local sources used in rifle \\ stock were used as experimental material. These materials were \\ technologically examined by drying the timber for a short time using a fully \\ automated, high frequency vacuum $(\mathrm{HF}+\mathrm{V})$ drying kiln. Physical and \\ mechanical properties of these tree species were compared after air \\ drying and $\mathrm{HF}+\mathrm{V}$ drying processes. There were no significant changes in \\ physical properties. However, the mechanical properties such as bending \\ strength, modulus of elasticity, compression strength, and dynamic \\ bending strength were decreased. According to these results, non- \\ overloaded areas like rifle stock can use high frequency vacuum drying as \\ the preferred drying method compared to conventional drying methods.
}

Keywords: High-frequency Vacuum; Drying; Oak; Walnut

Contact information: a: Department of Forest Industrial Engineering, Duzce University, 81620 Duzce, Turkey; b: Graduate student, Department of Forest Industry Engineering, 81620, Duzce, Turkey;

* Corresponding author: cengizguler@duzce.edu.tr

\section{INTRODUCTION}

At the beginning of the 20th century, significant improvements were achieved in wood drying by means of technical methods. Wood drying is the process of removing water from the wood material that is intended to use for lumber products manufacturing. An optimal drying process aims to maintain the quality of the material to be dried while keeping the drying time as short as possible and minimizing the drying costs (Kantay 1993).

Energy expenditure is long and extensive when using classical or traditional methods for lumber drying. The drying rate of wood in the conventional kilns depends greatly on the density and bond water diffusion rate and the role of wood permeability. It was stated that the drying time using the radio frequency vacuum method was reduced by $47 \%$ when compared to conventional kiln drying (Ananias et al. 2020). In addition, radio frequency vacuum kiln drying has been investigated in the case of three commercial softwood species (Avramidis and Zwick 1996). High temperature drying can reduce drying time, but this can cause drying defects such as discoloration, deformation, or cracking. In addition to various drying methods, radio frequency [RF] (dielectric method) can be used in combination with hot air to shorten the drying time (Miller 1966; Kobayashi et al. 1999; Lee and Jung 2000; Cai and Hayashi 2001; Resch and Gautsch 2001). 
The first studies on drying with high frequency electromagnetic radiation were carried out by Abramenko in 1934 and by Stephen and Holmquest in 1936. The first patent on high frequency drying was obtained by Luth and Krupnick in 1945. Subsequent studies were carried out by Miller in Canada in 1948 as well as Murata and Iso in Japan in 1949 (Resch 2006). Since the 1960s, many improvements have been made in high frequency drying in various countries (Jagfeld 1963; Gillwald 1964; Gefahrt 1967; Dean 1963; Miller 1966; Resch et al. 1970; Pound 1973).

Unlike the conventional drying method, high frequency vacuum drying systems stack lumber without using a sticker. This reduces the loading volume and makes it possible to use the suppressor system with compression. High frequency vacuum drying systems $(\mathrm{HF}+\mathrm{V})$ prevents the wood from moving during drying, which significantly reduces bending, buckling, crystallization, edgewise bending, curling, distortion, and other defects.

The wooden material is generally fed into the HF vacuum drying unit in the form of cylindrical autoclaved stacks stacked as a block, without a sticker. The lumber between the condenser plates are placed in stacks at particular intervals and in close contact with each other. This is heated in the presence of HF electromagnetic radiation followed by a quick and safe drying method performed by applying a vacuum force (Hansmann et al. 2008; Unsal et al. 2014) (Figs. 1 and 2).

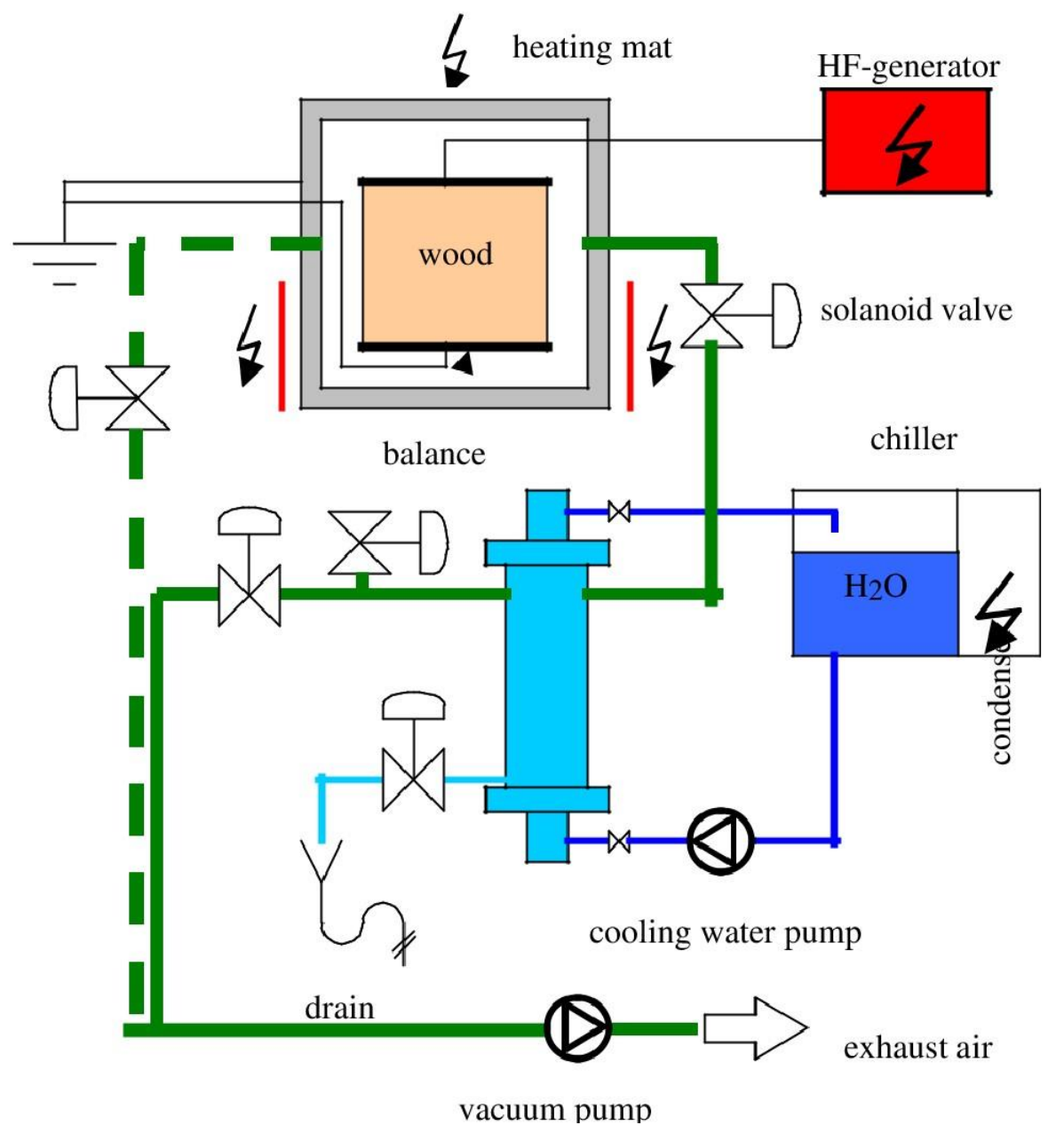

Fig. 1. High frequency + vacuum combination drying system (static method) (reprinted with permission from Resch, H., and Hansmann, C. (2002) 


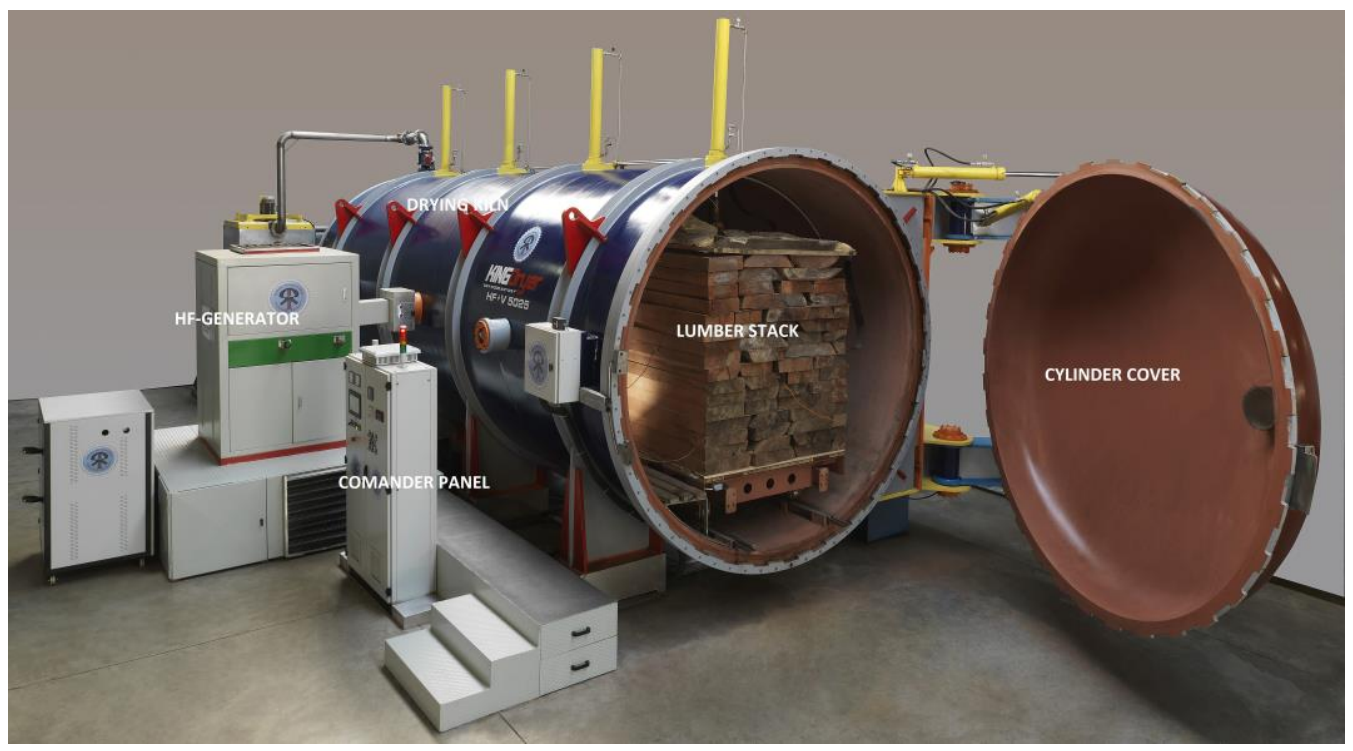

Fig. 2. High Frequency + Vacuum drying kiln

\section{EXPERIMENTAL}

\section{Air Drying}

One day before the oak and walnut lumber started drying, wet lumber was obtained by cutting oak in $6 \mathrm{~cm}$ thickness, common walnut lumber in $7.8 \mathrm{~cm}$ thickness, $30 \mathrm{~cm}$ width, and $150 \mathrm{~cm}$ in size. When cutting had been completed, the lumbers were left to dry naturally. Common oak (Quercus robur) and common walnut (Juglans regia) lumber were used in the study. The lumber was kept naturally and the moisture content was brought up to $13 \%$.

After the lumbers were dried naturally for a while, the test samples were cut in compliance with the standards and were conditioned at $65 \pm 5 \%$ relative humidity $(\mathrm{RH})$ and $20 \pm 1{ }^{\circ} \mathrm{C}$ in according to ISO 554 (1976). The analysis of T-test was applied using a randomized complete design to find out the statistically significant differences in the physical, mechanical, and dimensional properties of the samples. T-test at 5\% level of probability was conducted to study the significance of the differences among species using Statistical Analysis System (SPSS).

\section{Drying with High Frequency + Vacuum Method}

Oak lumber of $6 \mathrm{~cm}$ thickness and common walnut lumber of $7.8 \mathrm{~cm}$ thickness were processed in $\mathrm{HF}+\mathrm{V}$ drying kilns. The drying process brought their resultant moisture content up to 8 to $15 \%$ in accordance with the drying program (Tables 1 and 2).

\section{Test Standards}

In this study, density was determined according to the principles of 13061-2 (2014), volumetric shrinkage ISO 13061-14 (2016), and volumetric swelling ISO 13061-16 (2017).

The test of bending strength perpendicular to the grain, such as modulus of rupture (MOR) and modulus of elasticity (MOE), were performed according to ISO 13061-3 
(2014) and ISO 13061-4 (2014), respectively. Dynamic bending (shock) strength experiments were carried out according to ISO 13061-10 (2017) principles. The compression strength experiments were measured according to ISO 13061-17 (2017).

Table 1. 60 mm Thick Oak Timber HF + V Drying Program (Dilek 2019)

\begin{tabular}{|c|c|c|c|c|c|}
\hline $\begin{array}{c}\text { Timber Moisture } \\
\text { Contents } \\
(\%)\end{array}$ & $\begin{array}{l}\text { Temperature } \\
\left({ }^{\circ} \mathrm{C}\right)\end{array}$ & $\begin{array}{c}\text { Relative } \\
\text { Humidity (\%) } \\
\text { (After vacuum) }\end{array}$ & $\begin{array}{l}\text { Vacuum } \\
(-\mathrm{kPa})\end{array}$ & $\begin{array}{c}\text { Drying } \\
\text { Time } \\
\text { (h) }\end{array}$ & $\begin{array}{l}\text { Power } \\
\text { density } \\
\left(\mathrm{kW} / \mathrm{m}^{3}\right)\end{array}$ \\
\hline $65-60$ & $30-33$ & 8.1-9.4 & $0.400-0.600$ & \multirow{6}{*}{288} & \multirow{6}{*}{565} \\
\hline $60-50$ & $35-38$ & $7.4-8.0$ & $0.700-0.800$ & & \\
\hline $50-40$ & $39-42$ & $6.9-7.5$ & $0.850-0.900$ & & \\
\hline $40-30$ & $40-43$ & 6.2-7.0 & $0.900-0.960$ & & \\
\hline $30-20$ & $42-47$ & $5.1-5.5$ & $0.920-0.960$ & & \\
\hline $15-8$ & $44-48$ & $4.5-5.2$ & $0.930-0.970$ & & \\
\hline
\end{tabular}

Table 2. 78 mm Thick Walnut Timber HF + V Drying Program (Dilek 2019)

\begin{tabular}{|c|c|c|c|c|c|}
\hline $\begin{array}{c}\text { Timber Moisture } \\
\text { Contents } \\
(\%)\end{array}$ & $\begin{array}{l}\text { Temperature } \\
\left({ }^{\circ} \mathrm{C}\right)\end{array}$ & $\begin{array}{c}\text { Relative Humidity } \\
(\%) \\
\text { (After vacuum) }\end{array}$ & $\begin{array}{l}\text { Vacuum } \\
(-\mathrm{kPa})\end{array}$ & $\begin{array}{l}\text { Drying } \\
\text { Time } \\
\text { (h) }\end{array}$ & $\begin{array}{l}\text { Power } \\
\text { density } \\
\left(\mathrm{kW} / \mathrm{m}^{3}\right) \\
\end{array}$ \\
\hline $85-60$ & $35-40$ & $9.2-10.5$ & $\begin{array}{l}0.600- \\
0.700 \\
\end{array}$ & \multirow{6}{*}{192} & \multirow{6}{*}{541} \\
\hline $60-50$ & $40-44$ & $7.0-7.5$ & $\begin{array}{l}0.800- \\
0.850\end{array}$ & & \\
\hline $50-40$ & $42-48$ & 6.8-7.2 & $\begin{array}{l}0.900- \\
0.950 \\
\end{array}$ & & \\
\hline $40-30$ & $44-50$ & $5.9-6.5$ & $\begin{array}{c}0.910- \\
0.955 \\
\end{array}$ & & \\
\hline $30-20$ & $48-55$ & $5.2-5.7$ & $\begin{array}{l}0.925- \\
0.970\end{array}$ & & \\
\hline $15-8$ & $52-59$ & $4.3-4.8$ & $\begin{array}{l}0.930- \\
0.985\end{array}$ & & \\
\hline
\end{tabular}

\section{RESULTS AND DISCUSSION}

For oak, the average air-dry density was found to be $0.753 \mathrm{~g} / \mathrm{cm}^{3}$ in air drying and $0.749 \mathrm{~g} / \mathrm{cm}^{3}$ in $\mathrm{HF}+\mathrm{V}$ drying. For walnut, the average air-dry density was found to be $0.702 \mathrm{~g} / \mathrm{cm}^{3}$ in air drying and $0.691 \mathrm{~g} / \mathrm{cm}^{3}$ in $\mathrm{HF}+\mathrm{V}$ drying. A t-test was applied to determine whether there was a statistical difference between the air-dry density averages compared to the high frequency vacuum drying for each tree species (Table 3). The effect of oak samples dried with natural method and high frequency on air dry densities was not significant, with a 95\% level of confidence ( $p>0.05$ ).

As a result of $\mathrm{HF}+\mathrm{V}$ kiln drying process, there was no statistically significant difference compared to air-dry density values, and it can be stated that high frequency drying does not have a significant effect on air dry density values. The volumetric shrinkage and volumetric swelling test results are shown in Tables 4 and 5. 
Table 3. T-Test Results Related to the Air-Dry Density of Oak and Walnut Samples Test after Air Drying and HF + V Kiln Drying

\begin{tabular}{|l|l|l|l|l|l|}
\hline Drying method & $\mathrm{X}\left(\mathrm{g} / \mathrm{cm}^{3}\right)$ & $\mathrm{S}$ & $\mathrm{t}$-value & $\mathrm{df}$ & Sig. \\
\hline Oak air drying & 0.752 & 0.381 & 0.404 & 57.035 & 0.688 \\
\cline { 1 - 3 } Oak HF + V & 0.748 & 0.435 & & & \\
\cline { 1 - 3 } Walnut air drying & 0.702 & 0.325 & 1.353 & 57.987 & 0.181 \\
\cline { 1 - 2 } Walnut HF + V & 0.690 & 0.321 & & & \\
\hline
\end{tabular}

Table 4. T-Test Results for Volumetric Shrinkage Percentages of Oak and Walnut Samples Test after Air Drying and HF + V Kiln Drying

\begin{tabular}{|l|l|l|l|l|l|}
\hline Drying method & $\mathrm{X}(\%)$ & $\mathrm{S}$ & $\mathrm{t}$-value & $\mathrm{df}$ & Significance \\
\cline { 1 - 3 } Oak air drying & 12.675 & 1.841 & 0.667 & 52.622 & 0.508 \\
\cline { 1 - 3 } Oak HF + V & 12.951 & 1.322 & & & \\
\cline { 1 - 3 } Walnut air drying & 13.526 & 1.597 & 1.238 & 56.313 & 0.221 \\
\cline { 1 - 3 } Walnut HF + V & 12.965 & 1.902 & & & \\
\hline
\end{tabular}

Table 5. T-Test Results for Volumetric Swelling Percentages of Oak and Walnut Samples Test after Air Drying and HF + V Kiln Drying

\begin{tabular}{|l|l|l|l|l|l|}
\hline Drying method & $\mathrm{X}(\%)$ & $\mathrm{S}$ & t-value & df & Significance \\
\cline { 1 - 3 } Oak air drying & 15.379 & 1.066 & 1.314 & 35.935 & 0.197 \\
\cline { 1 - 3 } Oak HF + V & 16.157 & 3.060 & & & \\
\cline { 1 - 3 } Walnut air drying & 16.552 & 2.094 & 0.193 & 48.248 & \multirow{2}{*}{0.848} \\
\cline { 1 - 3 } Walnut HF + V & 16.693 & 3.398 & & & \\
\hline
\end{tabular}

The effect of oak and walnut samples dried by natural method and high frequency on the volumetric swelling rate was not significant with a 95\% level of confidence ( $p$ > $0.05)$.

In a study on the physical characteristics of trees that have industrial value in Turkey, volumetric shrinkage rate was found to be $12.2 \%$ in common oak wood. In common walnut wood, they stated the volume shrinkage as 13.4\% (Kantay et al. 2000; As et al. 2001). Shrinkage was found to be lower in radio frequency vacuum drying than in conventional kiln drying (Ananias et al. 2020). Korean ash squares, $66 \mathrm{~mm}$ thick and 100 $\mathrm{cm}$ long, to be used baseball bats, were dried in radio-frequency vacuum kiln a conventional kiln to compare drying times, shrinkage, checking and absorbed energy in impact bending. Absorbed energy in impact bending of squares dried in the RF/V kiln was about 14\% higher than that of squares dried in the conventional kiln (Lee and Jung 2000). The results obtained in this study were generally compatible with the literature. The drying process with $\mathrm{HF}+\mathrm{V}$ method does not have a significant effect on the shrinkage percentages of the wood material.

A t-test was applied to determine whether there was a statistical difference between the bending strength and modulus of elasticity averages compared to the high frequency vacuum drying for each tree species (Tables 6 and 7).

The effect of oak and walnut samples dried by natural method and high frequency on bending strength was found to be significant with $95 \%$ confidence in oak samples while it was found insignificant in walnut samples $(p>0.05)$. 
Table 6. T-Test Results Related to Bending Strength of Oak and Walnut Samples Test after Air Drying and HF+V Kiln Drying

\begin{tabular}{|l|l|l|l|l|l|}
\hline Drying method & $\mathrm{X}\left(\mathrm{N} / \mathrm{mm}^{2}\right)$ & $\mathrm{S}$ & $\mathrm{t}$-value & df & Significance \\
\hline Oak air drying & 88.824 & 8.312 & 3.136 & 26.933 & 0.004 \\
\cline { 1 - 3 } Oak HF+V & 78.189 & 10.170 & & & \\
\cline { 1 - 3 } Walnut air drying & 99.036 & 9.161 & 1.640 & 26.393 & 0.112 \\
\cline { 1 - 3 } Walnut HF+V & 92.714 & 11.786 & & & \\
\hline
\end{tabular}

As et al. (2001) determined bending strength in oak (Quercus robur) wood as 88 $\mathrm{N} / \mathrm{mm}^{2}$ and common walnut (Juglans regia) as $147 \mathrm{~N} / \mathrm{mm}^{2}$. Kantay et al. 2000 determined the bending strength of common walnut as $102 \mathrm{~N} / \mathrm{mm}^{2}$. In the present study, similar results were obtained in the bending strength of both oak and walnut in lumber obtained with the air-drying method. A $12 \%$ decrease in bending strength in oak processed with $\mathrm{HF}+\mathrm{V}$ drying was found to be statistically significant. The density of the oak is higher than walnut, and drying it with $\mathrm{HF}+\mathrm{V}$ is more difficult than walnut lumber. Therefore, it can be stated that the bonds between the fiber tissues weaken during drying due to drying intensity. As a result of the statistical comparison made between the bending strength values of walnut lumber as a result of both air drying and $\mathrm{HF}+\mathrm{V}$ drying, it was revealed that there was a $6 \%$ reduction in bending strength in walnut lumber.

Table 7. T-Test Results Related to the Modulus of Elasticity (MOE) of Oak and Walnut Samples Test after Air Drying and HF+V Kiln Drying

\begin{tabular}{|l|l|l|l|l|l|}
\hline Drying method & $\mathrm{X}\left(\mathrm{N} / \mathrm{mm}^{2}\right)$ & $\mathrm{S}$ & $\mathrm{t}$-value & df & Significance \\
\cline { 1 - 3 } Oak air drying & 8420.645 & 725.799 & 2.953 & 27.965 & 0.006 \\
\cline { 1 - 3 } Oak HF+V & 7623.782 & 752.017 & & & \\
\cline { 1 - 3 } Walnut air drying & 10062.763 & 2389.285 & \multirow{2}{*}{1.106} & \multirow{2}{*}{16.614} & 0.278 \\
\cline { 1 - 4 } Walnut HF+V & 9348.882 & 733.294 & & & \\
\hline
\end{tabular}

The effect of oak and walnut samples dried with air method and high frequency on the modulus of elasticity (MOE) in bending was not significant, at the $95 \%$ level of confidence $(\mathrm{p}>0.05)$.

As et al. (2001), in their study, determined the elastic modulus in oak (Quercus robur) wood as $11,700 \mathrm{~N} / \mathrm{mm}^{2}$ and common walnut (Juglans regia) as $12,500 \mathrm{~N} / \mathrm{mm}^{2}$. In this study, similar results were obtained in the elastic modulus of both oak and walnut in lumber obtained with air drying method. Consistent values were obtained in the elastic modulus of the oak with $\mathrm{HF}+\mathrm{V}$ drying application. The bending strength was found statistically significant with a decrease of about $9 \%$ occurring. The density of the oak is higher than walnut, and drying this material with $\mathrm{HF}+\mathrm{V}$ method is more difficult in comparison with walnut lumber. Therefore, the bonds between the fiber tissues weaken during drying due to drying intensity. As a result of the statistical comparison made between the elastic modulus values of walnut lumber as a result of both air drying and HF $+\mathrm{V}$ drying, it was revealed that there was a $7 \%$ reduction in elasticity module in walnut lumber.

The comprehensive strength and dynamic bending strength test results are shown in Tables 8 and 9. The effect of oak and walnut samples dried by air method and high frequency on the comprehensive strength was not significant at the $95 \%$ level of confidence $(\mathrm{p} \geq 0.05)$. 
Table 8. T-Test Results Related to Comprehensive Strength of Oak and Walnut Samples Test after Air Drying and HF+V Kiln Drying

\begin{tabular}{|l|l|l|l|l|l|}
\hline Drying method & $\mathrm{X}\left(\mathrm{N} / \mathrm{mm}^{2}\right)$ & $\mathrm{S}$ & $\mathrm{t}$-value & df & Significance \\
\hline Oak air drying & 46.971 & 3.405 & 3.216 & 25.191 & 0.04 \\
\cline { 1 - 3 } Oak HF+V & 43.508 & 2.406 & & & \\
\cline { 1 - 3 } Walnut air drying & 54.502 & 5.423 & 2.523 & 23.609 & 0.018 \\
\cline { 1 - 3 } & 50.326 & 3.418 & & & \\
\hline
\end{tabular}

As et al. (2001) determined the compression strength in stems of oak (Quercus robur) as $61 \mathrm{~N} / \mathrm{mm}^{2}$ and in ordinary walnuts (Juglans regia) as $72 \mathrm{~N} / \mathrm{mm}^{2}$. Kantay et al. (2000) determined the compression strength of common walnut as $38.82 \mathrm{~N} / \mathrm{mm}^{2}$. In the oak and walnut lumber with $\mathrm{HF}+\mathrm{V}$ drying process, there was a $7 \%$ decrease in the compression strength values, which was found statistically significant. The thick oak and walnut lumbers, which are resistant to drying process, are weakened by the HF + V drying process, and the bonds between the fiber tissues weaken due to the drying intensity.

Table 9. T-Test Results Related to Dynamic Bending (Shock) Strength of Oak and Walnut Test Samples after Air Drying and HF+V Kiln Drying

\begin{tabular}{|l|l|l|l|l|l|}
\hline Drying method & $\mathrm{X}(\mathrm{kN} / \mathrm{cm})$ & $\mathrm{S}$ & $\mathrm{t}$-value & df & Significance \\
\hline Oak air drying & 3.242 & 0.406 & 2.381 & 13.550 & 0.028 \\
\cline { 1 - 3 } Oak HF+V & 2.579 & 0.780 & & & \\
\cline { 1 - 3 } Walnut air drying & 5.055 & 0.693 & 2.030 & 14.301 & 0.057 \\
\cline { 1 - 3 } Walnut HF+V & 4.157 & 1.215 & & & \\
\hline
\end{tabular}

The effect of samples dried by air method and high frequency on the dynamic bending (Shock) strength was significant at the 95\% level of confidence ( $p>0.05$ ).

As et al. (2001) determined the dynamic bending (shock) strength of common oak (Quercus robur) as $0.60 \mathrm{kN} / \mathrm{cm}$ and common walnut (Juglans regia) as $0.95 \mathrm{kN} / \mathrm{cm}$. Kantay et al. (2000) stated the dynamic bending (shock) strength of common walnut as $0.54 \mathrm{kN} / \mathrm{cm}$. In oak lumber with $\mathrm{HF}+\mathrm{V}$ drying process, there was a $20 \%$ decrease in dynamic bending (shock) strength values and a $17 \%$ decrease in walnut lumber samples, which was found statistically significant. Hard-to-dry thick oak and walnut lumbers are partially deformed or torn apart in the cell cavities due to the rapid vacuuming of the water due to the drying intensity with the $\mathrm{HF}+\mathrm{V}$ drying process and this process can be expressed as the loosening of the fiber tissues.

\section{CONCLUSIONS}

1. The high frequency vacuum $(\mathrm{HF}+\mathrm{V})$ drying method does not have a significant effect on the wood material's air dry densities. In other words, there is no significant loss in wood material density with $\mathrm{HF}+\mathrm{V}$ drying. Moreover, $\mathrm{HF}+\mathrm{V}$ drying did not have a significant effect on volumetric shrinkage in oak and walnut in wood and water relationships. When the volumetric swelling properties were analyzed, oak and walnut were not statistically significant in dried timber obtained with $\mathrm{HF}+\mathrm{V}$ method. 
2. When the mechanical properties were examined, it was observed that $\mathrm{HF}+\mathrm{V}$ drying method had a significant effect on bending strength in oak and walnut lumber. There was a $12 \%$ loss in bending strength in oak lumber samples and $6 \%$ in walnut samples.

3. The modulus of elasticity showed a statistically significant decrease, as in the case of bending strength. Compared to control samples, there was $9 \%$ strength loss in oak and $7 \%$ in walnut samples.

4. The loss of strength in the control samples in terms of compression strength turned out to be statistically significant. According to the control samples at the end of $\mathrm{HF}+\mathrm{V}$ drying, a 7\% decrease in oak and walnut in compression strength was observed.

5. In shock strength tests, strength loss was higher as a result of $\mathrm{HF}+\mathrm{V}$ drying. Dynamic bending (shock) strength has decreased by $20 \%$ in oak and $17 \%$ in walnut.

6. There was a partial decrease in the mechanical properties of the wood material as a result of the $\mathrm{HF}+\mathrm{V}$ drying process. In addition, the drying process, which takes about 3 months with traditional methods, can be completed in about 10 days with this method. Therefore, the results of the study have shown that it is possible to dry some hard-todry tree species that are thicker than $5 \mathrm{~cm}$ and dry out in a short time up to 1/10 of the classical methods with this method. This will contribute significantly to the forest products industry and Turkey's economy.

7. The high frequency vacuum drying method is advantageous, especially in some places such as rifle stocks, where mechanical properties are not very important because of the short drying time.

8. The possibility of stacking without a lath increases the furnace feeding capacity by approximately $40 \%$.

9. With the reduced drying times, more lumber can be dried and naturally more timber can be offered to the market.

10. In this drying system, the fact that the drying of the wood material in the form of steam in the interior and at low temperatures reduces the stress caused by drying in the wood material.

11. Such methods, which use electricity effectively in lumber drying, cause much less damage to the environment than other methods.

12. Although this drying system is used in wood material drying today, it can also be preferred for drying agricultural products and other organic products.

13. In this drying system, it is possible to obtain pure water in the wood material with the help of vacuum, so that the pure water obtained from wood material can be used in agriculture and cosmetics.

14. As a result, the quality, drying time, cost, and technology of existing conventional drying kilns are insufficient. It is especially difficult to dry high value and thick timber with conventional drying kilns. It is possible to choose $\mathrm{HF}+\mathrm{V}$ drying technique for high density thick timber in a short time, especially for many places where mechanical properties are not very important. 


\section{ACKNOWLEDGMENTS}

The authors are grateful for the support of the U.S. Department of Ministry of Science Research, Grant No. 01214.STZ.2012-1 and thanks to the Recep SIVRİKAYA Co.

\section{REFERENCES CITED}

Abramenko, S. N. (1934). "The drying of wood by electric currents of high-frequency," Woodworking 10, 65-68.

Ananias, A. R., Villarroel V. S., Oena, P. N., Mella, J. T., Sepulveda S. L., Ulloa D. C., and Lira, C. S. (2020). "Radio frequency vacuum drying of Eucalyptus nitens juvenile wood," BioResources 15(3), 4886-4897.

Avramidis, S., and Zwick, R. L. (1996). "Commercial-scale RF/V drying of softwood lumber. Part 2. Drying characteristics and lumber quality," Forest Products Journal 46(6), 27-36.

As, N., Koç, H., Doğu, D., Atik, C., Aksu, B., and Erdinler, S. (2001). "Growing concern in Turkey anatomical industrial wood physical, mechanical, and chemical properties," Istanbul University Journal of Forestry Faculty 51(1), 71-88. DOI: 10.17099/jffiu.15049

Cai, Y., and Hayashi, K. (2001). "Compression and temperature distribution in wood during radio-frequency/vacuum drying," in: Proc. 7th Int. IUFRO Wood Drying Conference, Tsukuba, Japan, pp. 386-391.

Dean, A. R. (1963). "Drying timber by R.F.-Heating," Wood 28(2), 65.

Dilek, B. (2019). Some Physical and Mechanical Properties of Dried Lumber in Vacuum with High Frequency Heating, Master's Thesis, Duzce University, Duzce, Turkey.

Gefahrt, J. (1967). "High frequency heat in wood drying," Moderne Holzverarbeitung 2(5), 304.

Gillwald, W. (1964). "Fundamentals and prospects of high-frequency drying," Holzindustrie 17(2), 39.

Hansmann C. Stingl, R., Prieto, O. G., Lopez, C. B., and Resch, H. (2008). "Highfrequency energy-assisted vacuum drying of fresh Eucalyptus globulus," Drying Technology, 26: 611-616. DOI: 10.1080/07373930801946759

ISO 13061-2 (2014). "Physical and mechanical properties of wood - Test methods for small clear wood specimens - Part 2: Determination of density for physical and mechanical tests," International Organization for Standardization, Geneva, Switzerland.

ISO 13061-14 (2016). "Physical and mechanical properties of wood - Test methods for small clear wood specimens - Part 14: Determination of volumetric shrinkage," International Organization for Standardization, Geneva, Switzerland.

ISO 13061-16 (2017). "Physical and mechanical properties of wood -Test methods for small clear wood specimens - Part 16: Determination of volumetric swelling," International Organization for Standardization, Geneva, Switzerland. 
ISO 13061-3 (2014). "Physical and mechanical properties of wood - Test methods for small clear wood specimens - Part 3: Determination of ultimate strength in static bending," International Organization for Standardization, Geneva, Switzerland.

ISO 13061-4 (2014). "Physical and mechanical properties of wood - Test methods for small clear wood specimens - Part 4: Determination of modulus of elasticity in static bending," International Organization for Standardization, Geneva, Switzerland.

ISO 13061-10 (2017). "Physical and mechanical properties of wood - Test methods for small clear wood specimens - Part 10: Determination of impact bending strength," International Organization for Standardization, Geneva, Switzerland.

ISO 13061-17 (2017). "Physical and mechanical properties of wood -Test methods for small clear wood specimens - Part 17: Determination of ultimate stress in compression parallel to grain," International Organization for Standardization, Geneva, Switzerland.

ISO 554 (1976). Standard atmospheres for conditioning and/or testing - Specifications

Jagfeld, P. (1963). "The drying of wood in the high frequency alternating field," Holz-Zbl 89(10), 67.

Kantay, R. (1993). "Drying and Steaming of Lumber", Education and Culture Foundation, Publication No: 6, Istanbul.

Kantay, R., As, N., and Unsal, O. (2000). "The mechanical properties of walnut (Juglans regia L.) wood," Turk J. Agric. For. (24), 751-756.

Kobayashi, Y., Miura, I., and Kawai, Y. (1999). "High performance drying using combination of HF and hot air under atmospheric compression," in: Proc. 6th IUFRO Int. Wood Drying Conference, Stellenbosch, South Africa, pp. 18-21.

Lee, N. H., and Jung, H. S. (2000). "Comparison of shrinkage, checking, and absorbed energy in impact bending of Korean ash squares dried by a radio-frequency/vacuum process and a conventional kiln," Forest Products Journal 50(2), 69-69.

Luth, H. J., and Krupnick, S. R. (1945). "Method and apparatus for drying lumber," U.S. Patent No. 2,387.595.

Miller, D. G. (1966). "Radio-frequency lumber drying: Methods, equipment, and costs," Canad. Forest. Ind. 86(6), 53.

Murata, J., and Iso, H. (1949). "High frequency methods for wood drying," Mokuzai Kogyo [Wood Industry] 4, 250-256.

Pound, J. (1973). Radio Frequency Heating in the Timber Industry E. \& F.N. Spon Ltd. London, UK.

Resch, H. (2006). "High-frequency electric current for drying of wood - Historical perspectives,' Maderas. Ciencia y Tecnología 8(2), 67-82. DOI: 10.4067/S0718221X2006000200001

Resch, H., and Hansmann, C. (2002). "Tests to dry thick Eucalyptus boards in vacuum using high frequency heating," in: 4th Cost E15 Workshop, Santiago de Compostela, Spain, pp. 1-8.

Resch, H., Lofdahl, C. A., Smith, F. J., and Erb, C. (1970). "Moisture leveling in veneer by microwaves and hot air," Forest Prod. J. 20(10), 50-58.

Resch, H., and Gautsch, E. (2001). "High-frequency current/vacuum lumber drying," in: Proc. $7^{\text {th }}$ Int. IUFRO Wood Drying Conference, Tsukuba, Japan, pp. 128-133.

Stephen, J. L., and Holmquest, H. J. (1936). "Drying lumber with high frequency electric fields," Wood Products 41(10), 10-19. 
Unsal, O., Guler, C., Dilek, B., and Gorgun, H. V. (2014). "Drying performances of industrial high frequency and microwave driers in drying of some hardwoods," in: Proceedings of the $3^{\text {rd }}$ International Conference on Processing Technologies for the Forest and Bio-based Products Industries, Kuchl, Salzburg, Austria, pp. 187-190.

Article submitted: June 1, 2020; Peer review completed: July 19, 2020; Revised version received and accepted: August 18, 2020; Published: August 28, 2020.

DOI: $10.15376 /$ biores. 15.4.7861-7871 